\title{
Nutrient partitioning among the roots, hedge and cuttings of Corymbia citriodora stock plants
}

\author{
S. J. Trueman ${ }^{1 *}$, T. V. McMahon ${ }^{2}$, M. Bristow ${ }^{3}$ \\ ${ }^{1}$ Department of Agriculture, Fisheries and Forestry, University of the Sunshine Coast, Maroochydore DC, QLD 4558, \\ Australia. ${ }^{2}$ Faculty of Science, Health, Education and Engineering, University of the Sunshine Coast, Maroochydore DC, \\ QLD 4558, Australia. ${ }^{3}$ Research Institute for the Environment and Livelihoods, Charles Darwin University, Darwin, NT 0909, \\ Australia.*Corresponding author: strueman@usc.edu.au
}

\begin{abstract}
Many eucalypt species are difficult to propagate as rooted cuttings. The mineral nutrition of cuttings is a key factor that limits adventitious root induction but little is known about partitioning of nutrients by eucalypt stock plants. This study determined $\mathrm{N}, \mathrm{P}, \mathrm{K}, \mathrm{Ca}, \mathrm{B}, \mathrm{S}, \mathrm{Mg}, \mathrm{Mn}, \mathrm{Zn}, \mathrm{Al}, \mathrm{Fe}$ and $\mathrm{Na}$ concentrations in the root system, pruned hedge and harvested cuttings of stock plants of the eucalypt, Corymbia citriodora. Between $17 \%$ and $31 \%$ of total plant mass was collected as cuttings at each harvest. The mobile nutrients, $\mathrm{N}, \mathrm{K}$ and $\mathrm{S}$, were highly concentrated in the cuttings and were removed in high amounts (e.g. $27-46 \%$ of total plant $\mathrm{N}$ ) at each harvest, whereas less-mobile nutrients such as $\mathrm{Ca}$ and $\mathrm{Zn}$ were less concentrated in the cuttings than other plant parts. Adventitious rooting of eucalypt cuttings has been related to B concentration but this study revealed that B was much more highly concentrated in the hedge than the cuttings. Management of $\mathrm{N}$ and $\mathrm{K}$ concentrations for shoot production, and $\mathrm{B}$ concentrations for adventitious rooting, may be critical for sustaining rooted cutting production by C. citriodora.
\end{abstract}

Keywords: Boron, cloning, Eucalyptus, mineral nutrition, Myrtaceae, propagation

\section{Introduction}

The cuttings of some eucalypt species from riparian or high-rainfall habitats have a high capacity for forming adventitious roots (Wendling and Xavier, 2005; Saya et al., 2008; Goulart et al., 2011) but most plantation eucalypts are considered difficult to propagate from cuttings (Assis et al., 2004; Brondani et al., 2011, 2012a; Kilkenny et al., 2012). Difficulties with clonal propagation of woody plants have often been overcome by developing improved methods for managing their nursery stock plants and treating their harvested cuttings (Leakey, 2004 ; Pohio et al., 2005; Wendling et al., 2010; Majada et al., 2011). Mineral nutrition of cuttings is one of the key factors that limit adventitious rooting (Blazich, 1988; Xavier et al., 2009). However, in the absence of foliar fertilization, the nutritional status of cuttings is primarily determined by the nutritional status of the stock plant because there may be little nutrient uptake through the cut stump of cuttings before roots are formed (Grange and Loach, 1983; Blazich, 1988; Santos et al., 2009). 
One hypothesis for low adventitious rooting in subtropical eucalypts has been that $\mathrm{Ca}$ uptake into the young shoots of stock plants is limited when temperatures are suboptimal, and that root formation is correlated with Ca concentration (Assis et al., 2004). Subsequent studies have found that lowering the stock plant temperature does not affect the $\mathrm{Ca}$ concentration, and that rooting is usually not correlated with $\mathrm{Ca}$ concentration,in cuttings of three subtropical eucalypt species, Corymbia citriodora, Eucalyptus cloeziana and E. dunnii (Trueman et al., 2013a, b). However, adventitious root induction is consistently correlated with B concentration in cuttings of all three of these species (Trueman et al., 2013a, b) and it is often correlated with B concentration in clones of $E$. grandis $\times$ E.urophylla (Cunha et al., 2009a, b). Rooting is also correlated with $\mathrm{N}, \mathrm{P}$ and $\mathrm{K}$ concentrations in E. cloeziana, and with $\mathrm{P}$ and $\mathrm{K}$ concentrations in $C$. citriodora, but it is not correlated with concentrations of these macronutrients in E. dunnii, E. grandis, $E$. grandis $\times$ E.urophylla or E. urophylla (Cunha et al., 2009a, b; Trueman et al., 2013a, b). The partitioning of nutrients among the roots, pruned hedge and cuttings of stock plants has been described recently for $E$. urophylla (Neto et al., 2012) but, otherwise, little is known about the uptake and distribution of nutrients by eucalypt stock plants, despite their importance for determining the nutrient status and adventitious rooting potential of cuttings.

This study determined the distribution of $\mathrm{N}, \mathrm{P}, \mathrm{K}, \mathrm{Ca}$, $\mathrm{B}, \mathrm{S}, \mathrm{Mg}, \mathrm{Mn}, \mathrm{Zn}, \mathrm{Al}, \mathrm{Fe}$ and $\mathrm{Na}$ among the roots, the pruned hedge and the cuttings of C. citriodora stock plants. The aim was to reveal mobile nutrients that are lost from the stock plant at high rates during each harvest of cuttings and less-mobile nutrients that might not be transported to the young shoots in sufficient quantities to ensure high adventitious rooting. The study species is grown widely for its timber, pulp and essential oils (Dillon et al., 2012; Dickinson et al., 2013; Gbenou et al., 2013) but it is considered difficult to propagate as rooted cuttings (Shepherd et al., 2007; Trueman and Richardson, 2008; Trueman et al., 2013a). The results of this study will assist in developing fertilization strategies for sustainable shoot production and rooted cutting production by stock plants of C. citriodora.

\section{Materials and Methods}

The stock plants harvested in this study were a subsample of those used in the adventitious rooting study of Trueman et al. (2013a). Briefly, stock plants of C. citriodora subsp. variegata were raised in a glasshouse in Gympie (26 $11^{\circ} \mathrm{S}, 152^{\circ} 40^{\prime} \mathrm{E}$ ) by sowing seeds in January 2009 in potting mix consisting of a 75/25 (v/v) mixture of shredded pine bark and perlite, with $3 \mathrm{~kg}$ of $8-9$ month slow release Osmocote ${ }^{\mathrm{TM}}$ fertiliser (Scotts International, Heerlen, The Netherlands), $3 \mathrm{~kg}$ of lime (Unimin, Lilydale, Australia), $1 \mathrm{~kg}$ of gypsum (Queensland Organics, Narangba, Australia), $1 \mathrm{~kg}$ of Micromax TM granular micronutrients and $1 \mathrm{~kg}$ of Hydroflo ${ }^{\mathrm{TM}}$ soil wetting agent (both from Scotts Australia, Baulkham Hills, Australia) incorporated per $\mathrm{m}^{3}$. The $\mathrm{N}, \mathrm{P}$ and $\mathrm{K}$ contents of the Osmocote fertiliser were $16.0 \%$, $1.3 \%$ and $9.1 \%(\mathrm{w} / \mathrm{w})$, respectively, and the $\mathrm{pH}$ of the potting mix was approximately 6.5 .The seedlings were transplanted in February 2009 into 2.8L pots filled with the same potting mix, and then transferred randomly into four controlled-temperature glasshouse chambers in Nambour $\left(26^{\circ} 38^{\prime} \mathrm{S}, 152^{\circ} 56^{\prime} \mathrm{E}\right)$. Temperatures in all chambers were set at $28^{\circ} \mathrm{C} / 23{ }^{\circ} \mathrm{C}$ (day/night; 0600$1800 \mathrm{~h} / 1800-0600 \mathrm{~h}$, respectively). Irradiance was reported by Trueman et al. (2013a).

The seedlings were managed as hedged stock plants, commencing in April 2009, by pruning (i.e. hedging) at 3-week intervals to a height of $\sim 30 \mathrm{~cm}$ and a canopy diameter of $\sim 20 \mathrm{~cm}$. The temperatures in three of the chambers were changed randomly on 15 June 2009 to provide four temperatures across the four chambers: $18{ }^{\circ} \mathrm{C} / 13{ }^{\circ} \mathrm{C}, 23{ }^{\circ} \mathrm{C} / 18{ }^{\circ} \mathrm{C}, 28{ }^{\circ} \mathrm{C} / 23{ }^{\circ} \mathrm{C}$ and $33{ }^{\circ} \mathrm{C} / 28{ }^{\circ} \mathrm{C}$ (day/night). This date was regarded as the commencement of the experiment, consistent with the terminology in Trueman et al. (2013a, b). 
Temperatures and their corresponding stock plants were relocated randomly to different chambers every 4 weeks to minimise the effects of chamber.

Cuttings were harvested from all stock plants at 2, $5,8,11$ and 14 weeks after commencement of the experiment (Trueman et al., 2013a). For the current study, three stock plants from each temperature $(18$ ${ }^{\circ} \mathrm{C} / 13{ }^{\circ} \mathrm{C}, 23{ }^{\circ} \mathrm{C} / 18^{\circ} \mathrm{C}, 28{ }^{\circ} \mathrm{C} / 23{ }^{\circ} \mathrm{C}$ and $33^{\circ} \mathrm{C} / 28^{\circ} \mathrm{C}$ ) were destructively sampled at 2, 8 and 14 weeks (i.e. 12 stock plants on each sample date). All available cuttings were collected directly from each stock plant, and each stock plant was dissected into five complete parts: roots (R), hedge stems (HS), hedge leaves (HL), cutting stems (CS) and cutting leaves (CL). The roots were rinsed gently in water to remove adhering potting mix. The five plant parts were placed in separate paper bags, dried for $7 \mathrm{~d}$ at $65^{\circ} \mathrm{C}$, weighed, and ground using a Retsch MM200 tissue homogeniser (Retsch, Haan, Germany). The concentrations of $\mathrm{N}$ and $\mathrm{S}$ in each sample were determined by combustion analysis (McGeehan and Naylor, 1988; Rayment and Higginson, 1992) using a LECO CNS 2000. The concentrations of $\mathrm{P}, \mathrm{K}, \mathrm{Al}, \mathrm{B}, \mathrm{Ca}, \mathrm{Fe}, \mathrm{Mg}, \mathrm{Mn}$, $\mathrm{Na}$ and $\mathrm{Zn}$ were determined by inductively coupled plasma - atomic emission spectroscopy (Munter and Grande, 1981) after nitric and perchloric acid digestion (Martinie and Schilt, 1976).

Dry mass, nutrient concentrations and nutrient contents were analysed by 2-way ANOVA, comparing the five plant parts and four temperatures within each harvest date. Two-way ANOVA was used because extensive interactions between harvest date and the other factors (plant part and chamber temperature) were detected by 3-way ANOVA but temperature effects and interactions between plant part and temperature were generally not significant in the 2-way ANOVAs. Post-hoc least significant difference (LSD) tests were performed only when significant differences were detected by ANOVA. Data were square root or log transformed when variance was heterogeneous. Means are reported with standard errors, and mean differences or interactions were regarded as significant at $p<0.05$.

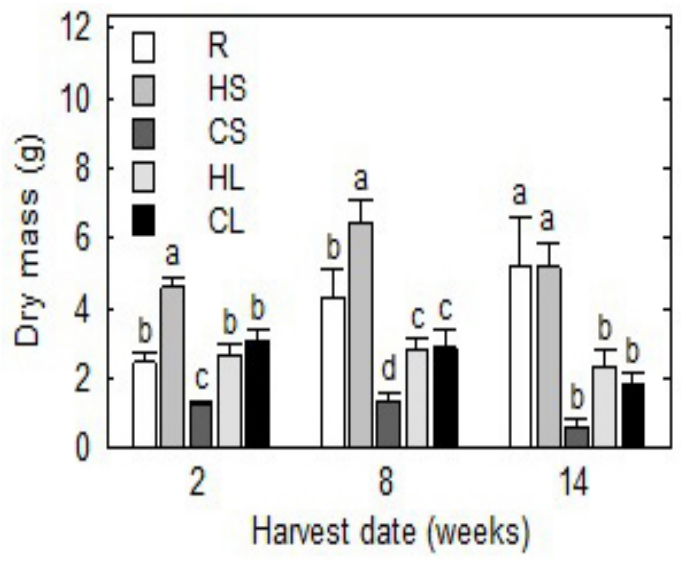

Figure 1. Dry mass partitioning among the roots (R), hedge stems (HS), cutting stems (CS), hedge leaves (HL) and cutting leaves (CL) of Corymbia citriodora stock plants at three harvest dates $(2,8$ and 14 weeks after commencement of the experiment). Means (+ s.e.) with different letters within a harvest date are significantly different (ANOVA and LSD test, $p<0.05$, $\mathrm{n}=12$ )

\section{Results and Discussion}

Much of the stem mass in C. citriodora stock plants was located in the main frame work of the hedge (HS) rather than in the cuttings (CS), whereas leaf mass was distributed almost equally between the hedge (HL) and the cuttings (CL) (Figure 1). Root mass $(\mathrm{R})$ increased during the experiment but the mass of available cuttings (CS + CL) declined at the final harvest date, as shown previously from the more-extensive harvests of cuttings from 18-24 stock plants (Trueman et al., 2013a). Between 17\% and 31\% of total plant mass was collected as cuttings at each harvest, with this percentage declining during the experiment (Table 1). These percentages were similar to those from the cuttings of E. urophylla stock plants $(\sim 18-25 \%)$ across a range of $\mathrm{N}$ application rates (Neto et al., 2012). 
Table 1. Biomass and nutrient losses (as percentages of whole-plant biomass or nutrient content) due to the harvest of cuttings from Corymbia citriodora stock plants at three sample times after commencement of the experiment.

\begin{tabular}{lccc}
\hline & \multicolumn{3}{c}{ Sample time } \\
\cline { 2 - 4 } & 2 weeks & 8 weeks & 14 weeks \\
\hline Biomass & $31 \pm 2$ & $22 \pm 3$ & $17 \pm 2$ \\
$\mathrm{~N}$ & $46 \pm 3$ & $30 \pm 4$ & $27 \pm 3$ \\
$\mathrm{P}$ & $36 \pm 3$ & $24 \pm 3$ & $17 \pm 2$ \\
$\mathrm{~K}$ & $42 \pm 3$ & $32 \pm 4$ & $26 \pm 3$ \\
$\mathrm{Ca}$ & $20 \pm 3$ & $12 \pm 3$ & $8 \pm 1$ \\
$\mathrm{~B}$ & $31 \pm 3$ & $23 \pm 4$ & $15 \pm 2$ \\
$\mathrm{~S}$ & $44 \pm 3$ & $29 \pm 4$ & $22 \pm 2$ \\
$\mathrm{Mg}$ & $36 \pm 3$ & $24 \pm 3$ & $19 \pm 2$ \\
$\mathrm{Mn}$ & $31 \pm 3$ & $21 \pm 3$ & $13 \pm 2$ \\
$\mathrm{Zn}$ & $21 \pm 3$ & $15 \pm 3$ & $12 \pm 2$ \\
$\mathrm{Al}$ & $10 \pm 2$ & $6 \pm 1$ & $5 \pm 1$ \\
$\mathrm{Fe}$ & $21 \pm 3$ & $9 \pm 1$ & $6 \pm 1$ \\
$\mathrm{Na}$ & $5 \pm 1$ & $1 \pm 0$ & $1 \pm 0$ \\
\hline
\end{tabular}

Means are provided with SE $(\mathrm{n}=12)$

Nitrogen was most concentrated in the hedge leaves and cutting leaves (HL and CL) and least concentrated in the stems of the hedge (HS) (Figure 2a), so that between $32 \pm 4$ and $88 \pm 7 \mathrm{mg}$ of $\mathrm{N}(\mathrm{CS}+\mathrm{CL})$ was lost from the stock plant during each harvest of cuttings (Figure 2b). Phosphorus concentration varied little within the plant (Figure 2c) and so the allocation of $\mathrm{P}$ (Figure 2d) reflected the allocation of dry mass to different parts of the stock plant (Figure 1; Table 1). Potassium was most concentrated in the leaves (HL and CL) and the cutting stems (CS) (Figure 2e), and stock plants lost between $33 \pm 5$ and $78 \pm 9 \mathrm{mg}$ of $\mathrm{K}(\mathrm{CS}+\mathrm{CL})$ at each harvest (Figure 2f). Therefore, disproportionately high amounts of total plant N (27$46 \%)$ and $\mathrm{K}(26-42 \%)$ were removed at each harvest (Table 1). These nutrients are highly mobile and are often concentrated in growing tissues such as young shoots (Karley and White, 2009; Li et al., 2010). Much greater percentages of total plant $\mathrm{N}(\sim 75-86 \%)$ are removed during the harvest of E. urophylla cuttings, which also lose disproportionately high amounts of total plant $\mathrm{P}(\sim 33-56 \%)$ and $\mathrm{K}(\sim 30-43 \%)$ at each harvest (Neto et al., 2012). Replacement of these mobile macronutrients may be critical for sustained stock plant growth as well as for root formation by cuttings, since adventitious rooting has been correlated with $\mathrm{P}$ and $\mathrm{K}$ concentrations in the cuttings of $C$. citriodora (Trueman et al., 2013a) and with N, P and K concentrations in E. cloeziana (Trueman et al., 2013b). However, rooting percentages are not correlated with $\mathrm{N}, \mathrm{P}$ and $\mathrm{K}$ concentrations in the cuttings of $E$. dunnii, E. grandis, E. grandis $\times$ E.urophylla and E. urophylla (Cunha et al., 2009 a, b; Trueman et al., 2013a).

Calcium concentrations were much higher in the roots $(\mathrm{R})$ and the hedge (HS and HL) than in the cuttings (CS and CL) (Figure 3a). Therefore, Ca loss through the harvest of cuttings (Figure $3 \mathrm{~b}$ ) was lower as a proportion of the plant's total nutrient content than it was for $\mathrm{N}, \mathrm{P}$ and $\mathrm{K}$ (Figures 2b, 2d, 2f; Table 1). In fact, disproportionately low amounts of $\mathrm{Ca}(8-20 \%)$ were lost through the harvest of cuttings (Table 1) in contrast with high losses ( $24-43 \%$ ) observed with E. urophylla (Neto et al., 2012). $\mathrm{Ca}$ is considered an immobile nutrient that tends to be retained at high levels in mature and senescing organs (McLaughlin and Wimmer, 1999; Karley and White, 2009). Its relatively low concentration in $C$. citriodora cuttings (CL: $0.73 \pm 0.07 \%$ to $0.79 \pm 0.07 \%$; Figure 3 a) could be a cause of reported low rooting percentages in this species (Shepherd et al., 2007; Trueman and Richardson, 2008; Trueman et al., 2013a). No correlation has been found between Ca concentration and rooting percentage in C. citriodora across a concentration range in whole cuttings of $0.57 \%$ to $1.12 \%$ (Trueman et al., 2013a) or in studies with E. cloeziana, E. dunnii, E. grandis $\times$ E.urophylla and E. urophylla (Cunha et al., 2009 a, b) Trueman et al., 2013a, b). 


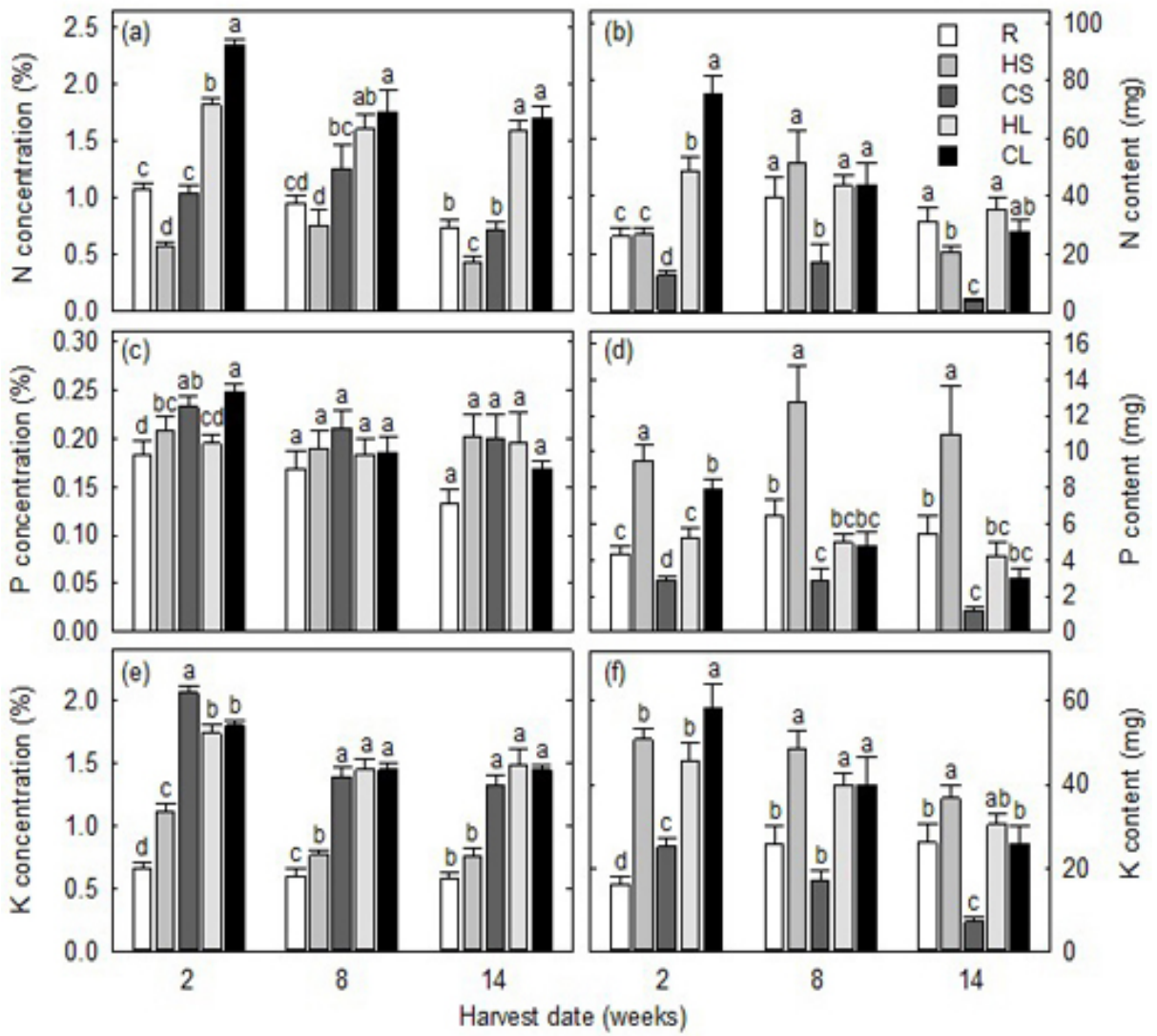

Figure 2. N, P and K partitioning among the roots (R), hedge stems (HS), cutting stems (CS), hedge leaves (HL) and cutting leaves (CL) of Corymbia citriodora stock plants at three harvest dates $(2,8$ and 14 weeks after commencement of the experiment). Means ( + s.e.) with different letters within a harvest date are significantly different (ANOVA and LSD test, $p<0.05, \mathrm{n}=12$ )

However, the $\mathrm{Ca}$ concentrations in C. citriodora cuttings in these studies were much lower than concentrations in the current hedge leaves $(1.90 \pm$ $0.11 \%$ to $2.00 \pm 0.16 \%$; Figure $3 \mathrm{a}$ ), and so there may be scope to improve adventitious rooting if Ca levels in the upper shoots can be increased greatly using foliar fertilizers, Ca supplements such as lime or gypsum, or optimised climatic regimes that increase Ca mobility.

Boron was more highly concentrated in the hedge leaves (HL) than the cutting leaves (CL) or other plant parts (R, HS and CS) (Figure 3c), resulting in much of the B content of the stock plant being confined to the hedge (HL and HS; Figure 3d). The proportion of total plant B removed through the harvest of cuttings (15-31\%) reflected the biomass allocation to cuttings (Table 1), as it did during the harvest of cuttings from E. urophylla (Neto et al., 2012). B is an immobile nutrient in many plant species where sucrose is the primary photoassimilate, but it is mobile in species that contain polyols such as sorbitol and mannitol (Miwa et al., 2009; Lehto et al., 2010) 

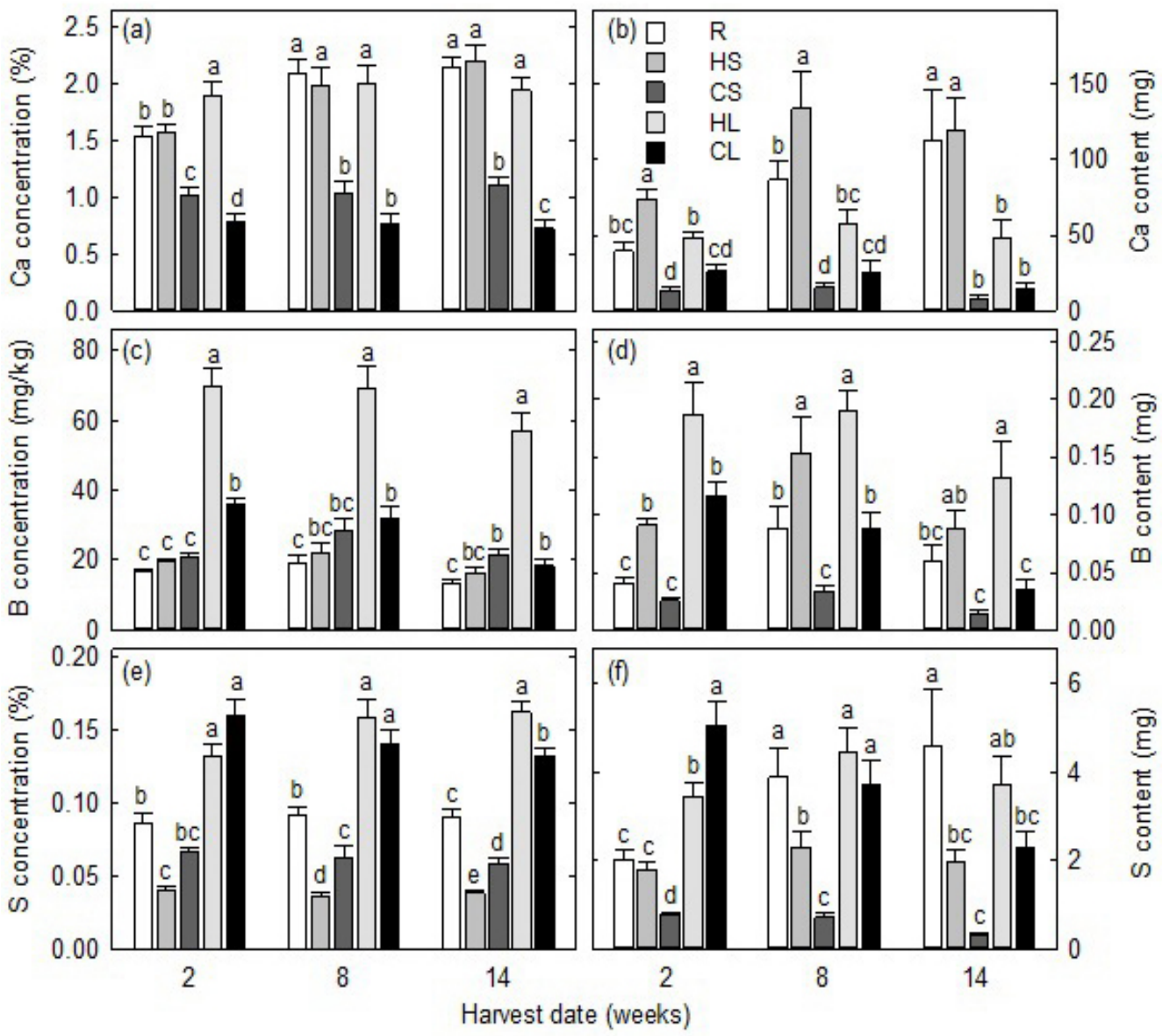

Figure 3. $\mathrm{Ca}, \mathrm{B}$ and $\mathrm{S}$ partitioning among the roots (R), hedge stems (HS), cutting stems (CS), hedge leaves (HL) and cutting leaves (CL) of Corymbia citriodora stock plants at three harvest dates $(2,8$ and 14 weeks after commencement of the experiment). Means ( + s.e.) with different letters within a harvest date are significantly different (ANOVA and LSD test, $p<0.05, \mathrm{n}=12$ )

E. grandis and E. grandis $\times$ E. urophylla are rich in sorbitol and mannitol (Leite et al., 2008, 2010), and B appears to be mobile in E. grandis $\times$ E. urophylla (Mattiello et al., 2009). Consistent relationships between $\mathrm{B}$ concentration and rooting percentage have been found in cuttings of C. citriodora, E. cloeziana and E. dunnii (Trueman et al., 2013a, b), and rooting percentages in three E. grandis $\times$ E. urophylla clones have been related to the concentration of $\mathrm{B}$ but not N, P, K or Ca (Cunha et al.,2009a, b). The effect of manipulating $\mathrm{B}$ concentration independently of other nutrients has rarely been assessed for adventitious root formation (Josten and Kutschera, 1999; Li et al., 2009; Xavier et al., 2009) but there appears to be great potential to improve rooted cutting production by increasing B levels in the young leaves of stock plants 
(i.e. in the cuttings). Boron can be supplied to stock plants as boric acid $\left(\mathrm{H}_{3} \mathrm{BO}_{3}\right)$, borax $\left(\mathrm{Na}_{2} \mathrm{~B}_{4} \mathrm{O}_{7} \cdot 10 \mathrm{H}_{2} \mathrm{O}\right)$, other sodium borates such as $\mathrm{Na}_{2} \mathrm{~B}_{4} \mathrm{O}_{7} \cdot 5 \mathrm{H}_{2} \mathrm{O}$, or through lesssoluble sources such as colemanite $\left(\mathrm{Ca}_{2} \mathrm{~B}_{6} \mathrm{O}_{11} \cdot 5 \mathrm{H}_{2} \mathrm{O}\right)$, ulexite $\left(\mathrm{NaCaB}_{5} \mathrm{O}_{9} \cdot 8 \mathrm{H}_{2} \mathrm{O}\right)$ or hydroboracite
$\left(\mathrm{CaMgB} \mathrm{O}_{11} \cdot 6 \mathrm{H}_{2} \mathrm{O}\right)$ that provide a more-prolonged release (Byers et al., 2001; Fageria et al., 2009). Supplementation with boric acid increases stock plant survival, shoot production and shoot quality in $E$. benthamii (Brondani et al., 2012b).
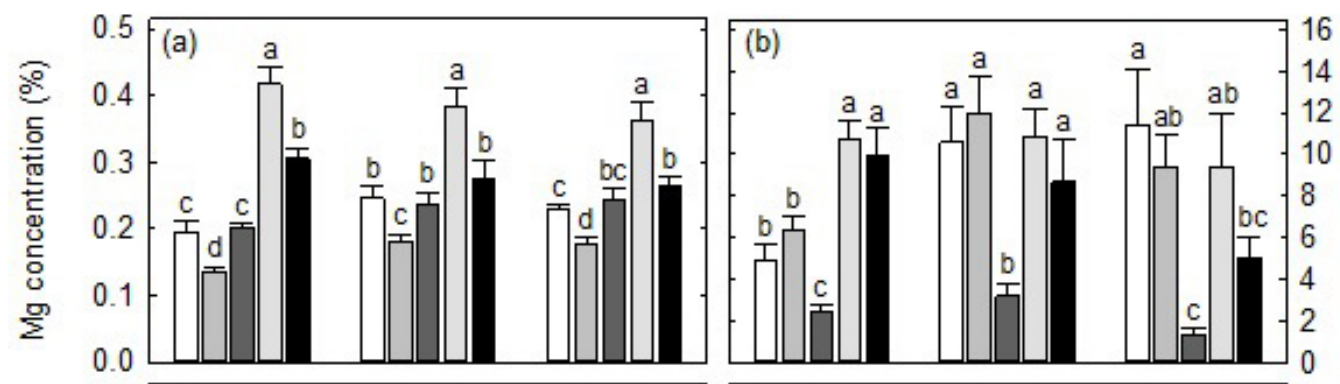

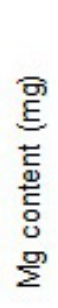

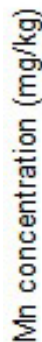
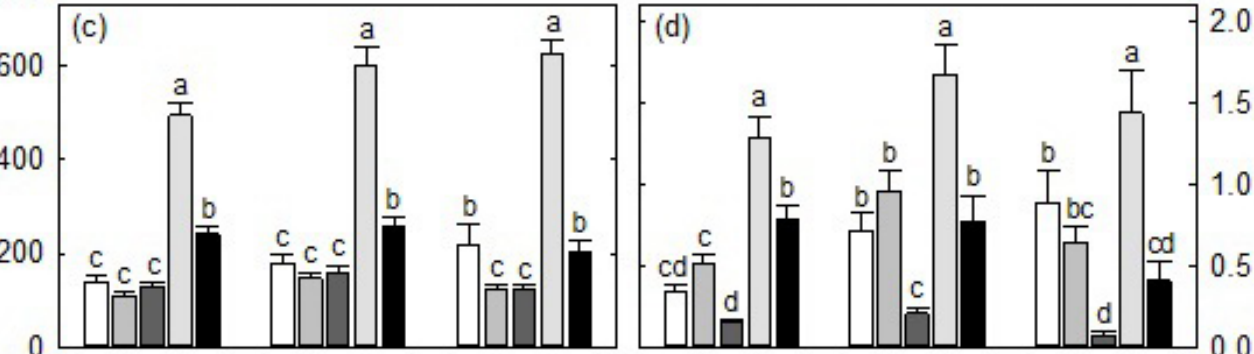

के

500 (e)

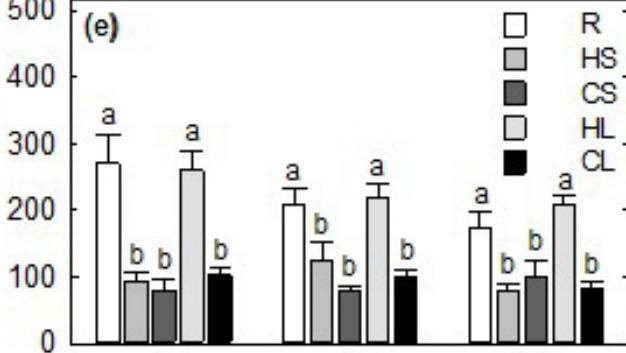

2
14
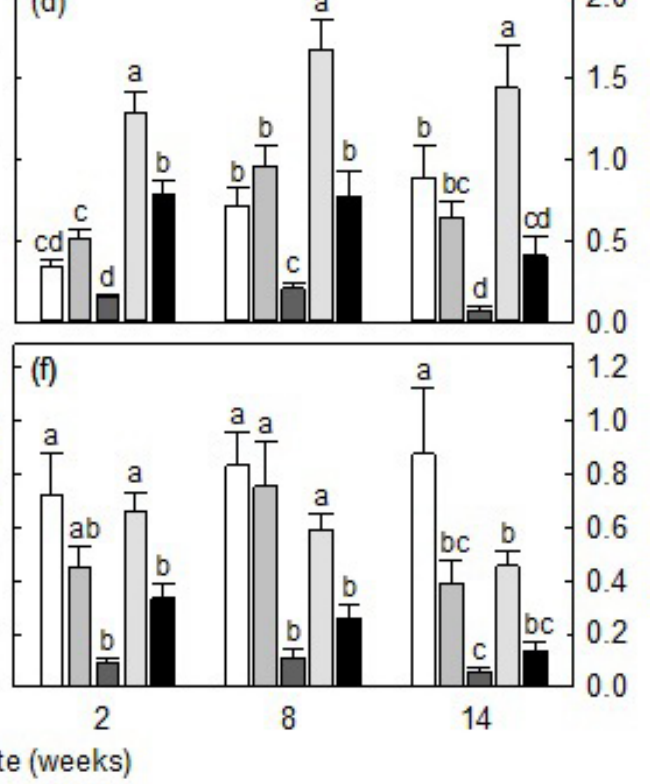

홍

Harvest date (weeks)

Figure 4. Mg, Mn and Zn partitioning among the roots (R), hedge stems (HS), cutting stems (CS), hedge leaves (HL) and cutting leaves (CL) of Corymbia citriodora stock plants at three harvest dates (2, 8 and 14 weeks after commencement of the experiment). Means (+ s.e.) with different letters within a harvest date are significantly different (ANOVA and LSD test, $p<0.05, \mathrm{n}=12$ ) 


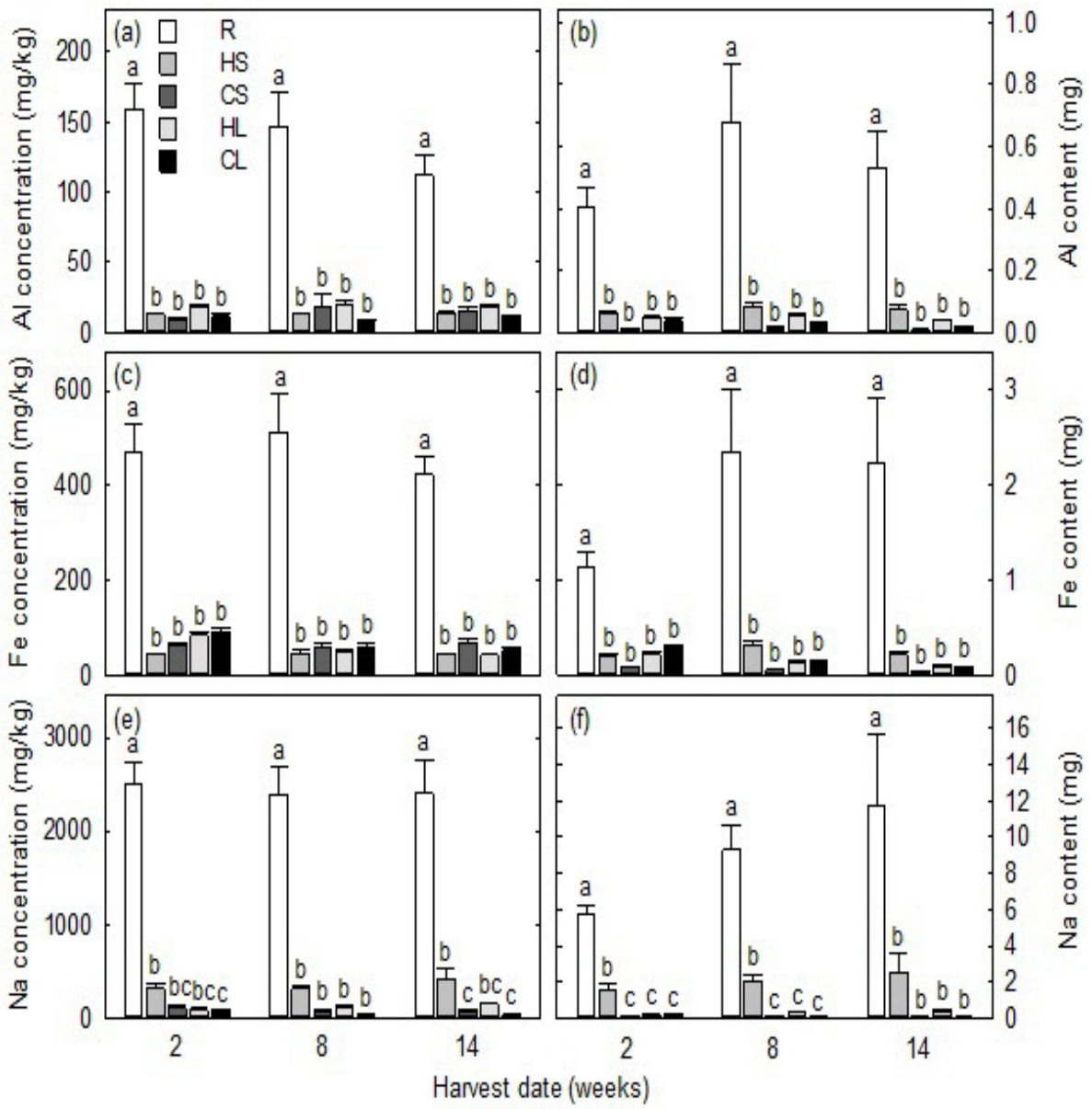

Figure 5. $\mathrm{Al}, \mathrm{Fe}$ and $\mathrm{Na}$ partitioning among the roots (R), hedge stems (HS), cutting stems (CS), hedge leaves (HL) and cutting leaves (CL) of Corymbia citriodora stock plants at three harvest dates $(2,8$ and 14 weeks after commencement of the experiment). Means ( + s.e.) with different letters within a harvest date are significantly different (ANOVA and LSD test, $p<0.05, \mathrm{n}=12$ )

Sulphur was also concentrated most highly in the leaves (Figures 3e, 3f), but with little or no difference in $\mathrm{S}$ concentration between the hedge leaves (HL) and cutting leaves (CL) (Figures 3e). Magnesium and manganese were concentrated most highly in the hedge leaves (HL) and, on some occasions, the cutting leaves $(\mathrm{CL})$ (Figures $4 \mathrm{a}-\mathrm{d}$ ).
Zinc was concentrated most highly in the hedge leaves (HL) and the roots (R) (Figures 4e, 4f). Disproportionately high amounts of total plant S (22$44 \%$ ) were removed from the stock plant as cuttings (Table 1), but $\mathrm{S}$ removal was not as high as the amount harvested ( $74-84 \%$ of total plant $S)$ in the cuttings of E. urophylla (Neto et al., 2012). Removals of Mg and 
$\mathrm{Mn}$ in cuttings were in proportion to the removal of biomass, while low proportions of total plant Zn (12$21 \%$ ) were in the cuttings (Table 1), similar to the low proportions ( $\sim 8-12 \%)$ found in E. urophylla cuttings (Neto et al., 2012). S and Mg are mobile nutrients that are often highly concentrated in young leaves (Hawkesford and De Kok, 2006; Karley and White, 2009; Maathuis, 2009). Mn is immobile in many species andis often highly concentrated in older leaves (Dučic et al., 2006; Page et al., 2006, 2012) including those of eucalypts, which are often considered as $\mathrm{Mn}$ accumulators (Hill et al., 2001; Jobbágy and Jackson, 2004). Zn mobility is considered to be intermediate between highly mobile elements such as $\mathrm{K}$ and $\mathrm{P}$ and immobile elements such as $\mathrm{Ca}$, but $\mathrm{Zn}$ is often highly concentrated in roots and older leaves (Page and Feller, 2005; Ivanov et al., 2011). Rooting percentages have been positively correlated with $\mathrm{Zn}$ concentrations in the cuttings of three E. grandis $\times$ E. urophylla clones (Cunha et al., 2009b) but not in C. citriodora, E. cloeziana, E. dunnii, E. grandis or E. urophylla (Cunha et al., 2009 a, b; Trueman et al., 2013a, b). However, the $\mathrm{Zn}$ concentrations in E. grandis $\times E$. urophylla cuttings $(36-45 \mathrm{mg} / \mathrm{kg}$ ) were much lower than those in C. citriodora (Figure 4e).

Aluminium, iron and sodium were concentrated more highly in the roots (R) than in any of the above-ground plant parts, so that most of the $\mathrm{Al}, \mathrm{Fe}$ and $\mathrm{Na}$ content of the plant was contained within the roots and only a low proportion was within the cuttings (Figure 5). The proportion (6-21\%) of total plant $\mathrm{Fe}$ in the cuttings (Table 1) was similar to the low proportion (9-15\%) in E. urophylla cuttings (Neto et al., 2012). Fe is an actively-transported nutrient that is required for photosynthesis and mitochondrial respiration (Hänsch and Mendel, 2009; Puig and Peñarrubia, 2009) but is often concentrated most highly in the roots (Gomes et al., 2012; Neto et al., 2012). Al is also concentrated in roots and returned to the soil through a variety of efflux mechanisms, but some plants immobilize Al in the root symplast external to the endodermis (Vázquez, 2002; Nguyen et al., 2005; Zheng et al., 2005). Na is also concentrated in the roots and excluded from reaching the shoots of many species to maintain high photosynthetic rates (Hauser and Horie, 2010; Edelstein et al., 2011). Rooting percentages are generally not correlated with Fe concentration in eucalypt cuttings (Cunha et al., 2009 a, b; Trueman et al., 2013a, b), but rooting has been correlated positively with $\mathrm{Na}$ and $\mathrm{Al}$ concentrations in the cuttings of $C$. citriodora and $E$. dunnii, respectively (Trueman et al., 2013a).

\section{Conclusion}

This study has revealed the partitioning of biomass and nutrients among the roots, hedge and cuttings of Corymbia stock plants. Between $17 \%$ and $31 \%$ of total plant mass was harvested from the stock plants at each collection of cuttings, but some mobile nutrients $(\mathrm{N}$, $\mathrm{K}$ and S) were highly concentrated in the cuttings and were disproportionately lost from the stock plant during each harvest of cuttings. More-immobile elements ( $\mathrm{Ca}$ and $\mathrm{Zn}$ ) were less concentrated in the cuttings than other parts of the stock plant. Importantly, B was more highly concentrated in leaves of the hedge than in leaves of the cuttings. Short-term management of B concentration in cuttings and longer-term management of the $\mathrm{N}$ and $\mathrm{K}$ supply to stock plants may be critical for sustaining high levels of rooted cutting production by C. citriodora and other eucalypt species.

\section{Acknowledgements}

Thanks to Elektra Grant, Jeremy Drimer, Brooke Dwan, Laura Simmons, Rebecca Creedy, Justin Sanderson, Michael Nielsen, Donna Richardson, Tracey Menzies, Bevan Zischke and Robert Juster for assistance, and Tim Smith and Mark Hunt for useful discussions. The study was funded by the Queensland National and International Research Alliances Program and the Queensland Plantation Hardwoods Research Fund. 


\section{References}

Assis, T.F., Fett-Neto, A.G., Alfenas, A.C. 2004 Current techniques and prospects for the clonal propagation of hardwoods with emphasis on Eucalyptus. In: C. Walter, M. Carson (eds). Plantation Forest Biotechnology for the 21st Century.Research Signpost, Kerala, India, pp: 303-333.

Blazich, F.A.1988. Mineral nutrition and adventitious rooting. In: T.D. Davis, B.E. Haissig, N. Sankhla (eds). Adventitious Root Formation in Cuttings. Dioscorides Press, Portland, Oregon, pp: 61-69.

Brondani, G.E., Dutra, L.F., Wendling, I., Grossi, F., Hansel, F.A., Araujo, M.A. 2011. Micropropagation of an Eucalyptus hybrid (Eucalyptus benthamii $\times$ Eucalyptus dunnii). Acta Sci. Agron. 33, 655-663.

Brondani, G.E., Wendling, I., Brondani, A.E., Araujo, M.A., Silva, A.L.L., Gonçalves, A.N. 2012a. Dynamics of adventitious rooting in minicuttings of Eucalyptus benthamii $\times$ Eucalyptus dunnii. Acta Sci. Agron. 34, 169-178.

Brondani, G.E., Baccarin, F.J.B., Ondas, H.W.W., Gonçalves, A.N., Almeida, M. 2012b. Avaliação morfológica e produção de minijardim clonal de Eucalyptus benthamii em relação a Zn e B. Pesq. Flor. Bras. 32, 151-164.

Byers, D.E., Mikkelsen, R.L., Cox, F.R. 2001. Greenhouse evaluation of four boron fertilizer materials. J. Plant Nutr. 24, 717-725.

Cunha, A.C.M.C.M., Paiva, H.N., Barros, N.F., Leite, H.G., Leite, F.P. 2009a. Relaçaõ do estado nutricional de minicepas com o enraizamento de miniestacias de eucalipto. Rev.Bras.Ciênc. Solo 33, 591-599.

Cunha, A.C.M.C.M., Paiva, H.N., Leite, H.G., Barros, N.F., Leite, F.P. 2009b. Influência do estado nutricional de minicepas no enraizamento de miniestacas de eucalipto. Rev. Árvore 33, 607615 .

Dickinson, G.R., Wallace, H.M., Lee, D.J. 2013. Reciprocal and advanced generation hybrids between Corymbia citriodora and C. torelliana: forestry breeding and the risk of gene flow. Ann. For. Sci. 70, 1-10.

Dillon, S.K., Brawner, J.T., Meder, R., Lee, D.J., Southerton, S.G. 2012. Association genetics in Corymbia citriodora subsp. variegata identifies single nucleotide polymorphisms affecting wood growth and cellulosic pulp yield. New Phytol. 195, 596-608.

Dučic, T., Leinemann, L., Finkeldey, R., Polle, A. 2006. Uptake and translocation of manganese in seedlings of two varieties of Douglas fir (Pseudotsuga menziesii var. viridis and glauca). New Phytol. 170, 11-20.

Edelstein, M., Plaut, Z., Ben-Hur, M. 2011.,Sodium and chloride exclusion and retention by nongrafted and grafted melon and Cucurbita plants. J. Exp. Bot. 62, 177-184.

Fageria, N.K., Barbosa, Filho, M.P., Moreira, A., Guimarães, C.M. 2009. Foliar fertilization of crop plants. J. Plant Nutr. 32, 1044-1064.

Gbenou, J.D., Ahounou, J.F., Akakpo, H.B., Laleye, A., Yayi, E., Gbaguidi, F., Baba-Moussa, L., Darboux, R., Dansou, P., Moudachirou, M., Kotchoni, S.O. 2013. Phytochemical composition of Cymbopogon citratus and Eucalyptus citriodora essential oils and their anti-inflammatory and analgesic properties on Wistar rats. Mol. Biol. Rep. 40, 1127-1134.

Gomes, M.P., Marques, T.C.L.L.S.M., Carneiro, M.M.L.C., Soares, Â.M. 2012. Anatomical characteristics and nutrient uptake and distribution associated with the Cd-phytoremediation capacity 
of Eucalyptus camaldulensis Dehnh. J. Soil Sci. Plant Nutr. 12, 481-495.

Goulart, P.B., Xavier, A., Dias, J.M.M. 2011. Efeito dos cofatores hidroquinona, prolina e triptofano no enraizamento de miniestacas de clones de Eucalyptus grandis $\times$ E. urophylla . Rev. Árvore 35, 1017-1026.

Grange, R.I., Loach, K. 1983. The water economy of un rooted leafy cuttings. J. Hortic. Sci. 58, 9-17.

Hänsch, R., Mendel, R.R. 2009. Physiological functions of mineral micronutrients $(\mathrm{Cu}, \mathrm{Zn}, \mathrm{Mn}$, Fe, Ni, Mo, B, Cl). Curr. Opin. Plant Biol. 12, 259-266.

Hauser, F., Horie, T. 2010. A conserved primary salt tolerance mechanism mediated by HKT transporters: a mechanism for sodium exclusion and maintenance of high $\mathrm{K}^{+} / \mathrm{Na}^{+}$ratio in leaves during salinity stress. Plant Cell Environ. 33, $552-565$.

Hawkesford, M.J., De Kok, L.J. 2006. Managing sulphur metabolism in plants. Plant Cell Environ. 29, 382-395.

Hill, J., Attiwill, P.M., Uren, N.C., O'Brien, N.D. 2001. Does manganese play a role in the distribution of the eucalypts?. Aust. J. Bot. 49, $1-8$.

Ivanov, Y.V., Savochkin, Y.V., Kuznetsov, V.V. 2011. Scots pine as a model plant for studying the mechanisms of conifers adaptation to heavy metal action: 1. Effects of continuous zinc presence on morphometric and physiological characteristics of developing pine seedlings. Russ. J. Plant Physiol. 58, 871-878.

Jobbágy, E.G., Jackson, R.B., 2004. The uplift of soil nutrients by plants: biogeochemical consequences across scales. Ecol. 85, 2380-2389.
Josten, P., Kutschera, U. 1999. The micronutrient boron causes the development of adventitious roots in sunflower cuttings. Ann. Bot. 84, 337-342.

Karley, A.J., White, P.J. 2009. Moving cationic minerals to edible tissues: potassium, magnesium, calcium. Curr. Opin. Plant Biol. 12, 291-298.

Kilkenny, A.J., Wallace, H.M., Walton, D.A., Adkins, M.F., Trueman, S.J. 2012. Improved root formation in eucalypt cuttings following combined auxin and anti-ethylene treatments. J. Plant Sci. 7, 138-153.

Leakey, R.R.B. 2004. Physiology of vegetative reproduction. In: J. Burley, J. Evans, J.A. Youngquist(eds). Encyclopaedia of Forest Sciences. Academic Press, London, UK, pp: 1655-1668.

Lehto, T., Ruuhola T., Dell, B. 2010. Boron in forest trees and ecosystems. For. Ecol. Manag. 260, 2053-2069.

Leite, S.M.M., Valle, C.F., Bonine, C.A.V., Marino, C.L. 2008. Boron influence on concentration of polyols and other sugars in Eucalyptus. Rev. Árvore 32, 815-820.

Leite, S.M.M., Marino, C.L., Bonine, C.A.V. 2010. Respostas de clones de Eucalyptus grandis e E. grandis $\times$ E. urophylla à supressão de boro. Sci. For. 38, 19-25.

Li, S.-W., Xue, L., Xu, S., Feng, H., An, L. 2009. Mediators, genes and signalling in adventitious rooting. Bot. Rev. 75, 230-247.

Li, A., Guo, D., Wang, Z., Liu, H. 2010. Nitrogen and phosphorus allocation in leaves, twigs, and fine roots across 49 temperate, subtropical and tropical tree species: a hierarchical pattern. Funct. Ecol. 24, 224-232.

Maathuis, F.J.M. 2009. Physiological functions of mineral macronutrients. Curr. Opin. Plant Biol. 12, 250-258. 
Majada, J., Martínez-Alonso, C., Feito, I., Kidelman, A., Aranda, I., Alía, R. 2011. Mini-cuttings: an effective technique for the propagation of Pinus pinaster. New For. 41, 399-412.

Martinie, G.D., Schilt ,A.A. 1976. Investigation of wet oxidation efficiencies of perchloric acid mixtures for various organic substances and identities of residual matter. Anal. Chem.48, 70-74.

Mattiello, M.E., Ruiz, H.A., Silva, I.R., Sarkis, J.E.S., Neves, J.C.L., Pucci, M.M. 2009. Phloem mobility of boron in two eucalypt clones. Rev. Bras. Ciênc. Solo 33, 1695-1704.

McGeehan, S.L., Naylor, D.V. 1988. Automated instrumental analysis of carbon and nitrogen in plant and soil samples. Commun. Soil Sci. Plant Anal.19, 493-505.

McLaughlin, S.B., Wimmer, R. 1999. Calcium physiology and terrestrial ecosystem processes. New Phytol. 142, 373-417.

Miwa, K., Kamiya, T., Fujiwara, T. 2009. Homeostasis of the structurally important micronutrients, $\mathrm{B}$ and Si. Curr. Opin. Plant Biol. 12, 307-311.

Munter, R.C., Grande, R.A. 1981. Plant tissue and soil extract analysis by ICP - atomic emission spectrometry. In: R.M. Barnes (ed.). Developments in Atomic Plasma Spectrochemical Analysis. Heyden, London, UK, pp: 653-672.

Neto, J.P.C., Silva, E.B., Santana, R.C., Grazziotti, P.H., Fernandes, J.S.C., Freitas, J.P.X., Souza, C.V. 2012. Partição de biomassa seca nutriente em minicepas de eucalipto influenciada pela adubação NPK. Ciênc. Florest. 22, 467-476.

Nguyen, N.T., Dudzinski, M.J., Mohapatra, P.K., Fujita, K. 2005. Distribution of accumulated aluminum and changes in cell wall polysaccharides in Eucalyptus camaldulensis and Melaleuca cajuputi under aluminum stress. Soil Sci. Plant Nutr. 51, 737-740.
Page, V., Feller, U. 2005. Selective transport of zinc, manganese, nickel, cobalt and cadmium in the root system and transfer to the leaves in young wheat plants. Ann. Bot. 96, 425-434.

Page, V., Le Bayon, R.-C., Feller, U. 2006. Partitioning of zinc, cadmium, manganese and cobalt in wheat (Triticum aestivum) and lupin (Lupinus albus) and further release into the soil. Environ. Exp. Bot. 58, 269-278.

Page, V., Blösch, R.M., Feller, U. 2012. Regulation of shoot growth, root development and manganese allocation in wheat (Triticum aestivum) genotypes by light intensity. Plant Growth Regul. 67, 209215.

Pohio, K.E., Wallace, H.M., Peters, R.F., Smith, T.E., Trueman, S.J. 2005. Cuttings of Wollemi pine tolerate moderate photoinhibition and remain highly capable of root formation. Trees. 19, 587595.

Puig, S., Peñarrubia, L. 2009. Placing metal micronutrients in context: transport and distribution in plants. Curr. Opin. Plant Biol. 12, 299-306.

Rayment, G.E., Higginson, F.R. 1992. Australian Laboratory Handbook of Soil and Water Chemical Methods. Inkata, Melbourne, Australia, 330 pp.

Santos, K.M., Fisher, P.R., Argo, W.R. 2009. Stem versus foliar uptake during propagation of Petunia $\times$ hybrida vegetative cuttings. HortSci. 44, 1974-1977.

Saya, R.A., Mankessi, F., Toto, M., Marien, J.-N., Monteuuis, O. 2008. Advances in mass clonal propagation of Eucalyptus urophylla $\times$ E. grandis in Congo. Bois For. Trop. 297, 15-25.

Shepherd, M., Pomroy, P., Dieters, M., Lee, D. 2007. Genetic control of propagation traits in a single Corymbia torelliana $\times$ Corymbia variegata family. Can. J. For. Res. 37, 2563-2574. 
Trueman, S.J., Richardson, D.M. 2008. Relationships between indole-3-butyric acid, photoinhibition and adventitious rooting of Corymbia torelliana, C. citriodora and F1 hybrid cuttings. Tree For. Sci. Biotechnol. 2, 26-33.

Trueman, S.J., McMahon, T.V., Bristow, M. $2013 \mathrm{a}$. Production of cuttings in response to stock plant temperature in the subtropical eucalypts, Corymbia citriodora and Eucalyptus dunnii. New For. 44, 265-279.

Trueman, S.J., McMahon, T.V., Bristow, M. 2013b. Production of Eucalyptus cloeziana cuttings in response to stock plant temperature. J. Trop. For. Sci. 25, 60-69.

Vázquez, M.D. 2002. Aluminum exclusion mechanism in root tips of maize (Zea mays L.): lysigeny of aluminum hyperaccumulator cells. Plant Biol. 4, 234-249.
Xavier, A., Wendling, I., Silva, R.L. 2009. Silvicultura Clonal: Princípios e Técnicas. Editora UFV, Viçosa, Brazil, 272 pp.

Wendling, I., Xavier, A. 2005. Influência do ácido indolbutírico e da miniestaquia seriada no enraizamento e vigor de miniestacas de clones de Eucalyptus grandis. Rev. Árvo. 29, 921-930.

Wendling, I., Brondani, G.E., Dutra, L.F., Hansel, F.A. 2010. Mini-cuttings technique: a new ex vitro method for clonal propagation of sweetgum. New For. 39, 343-353.

Zheng, S.J., Yang, J.L., He, Y.F., Yu, X.H., Zhang, L., You, J.F., Shen, R.F., Matsumoto, H. 2005. Immobilization of aluminum with phosphorus in roots is associated with high aluminum resistance in buck wheat. Plant Physiol. 138, 297-303. 